\title{
Transforming Transport Unions through Mass Organisation of Informal Workers: A Case Study of the ATGWU in Uganda ${ }^{1}$
}

\author{
Dave Spooner, Global Labour Institute, United Kingdom \\ John Mark Mwanika, ATGWU, Uganda
}

\begin{abstract}
This paper analyses the power resources of informal transport workers in Uganda, and the transformation processes of the Amalgamated Transport and General Workers' Union (ATGWU) and their newly affiliated informal workers' associations in organising informal workers. We examined the process of organisation, how strategic choices were made, and how the expected increases in power resources were realised. We also analysed the critical factors behind the success of the strategy, as well as the lessons learned and the unresolved challenges. The ATGWU faced an almost complete collapse in membership following the impact of structural adjustment programmes in the 1980s, and the subsequent informalisation of the transport industry. In recent years, it has pioneered a strategy of organising through the affiliation of mass-membership associations of informal workers, notably representing minibus taxi workers and motorcycle taxi ("boda-boda") riders. The unionisation of informal workers has had a dramatic impact: a reduction in police harassment, substantial gains through collective bargaining, reduced internal conflict within the associations, and improvement of visibility and status for informal women transport workers. The rapid expansion has raised new challenges for the union, particularly in the transition to a fully integrated formal-informal organisation, the need for reform of democratic process and accountability, and the maintenance of solidarity between informal and formal workers.
\end{abstract}

\section{KEYWORDS}

informal workers; trade unions; transport; Uganda; ATGWU

\section{Organising Informal Workers}

There is a considerable literature which describes the multitude of grassroots organisational forms and approaches that have emerged in response to challenges and limitations faced by informal workers and their organisations, reflecting contextual and sector-specific factors. Much of this has been developed through studies of home-based workers, domestic workers, waste recyclers, street vendors and market traders, particularly through the experience of the Organisation and Representation Programme of Women in Informal Employment: Globalizing and Organizing

${ }^{1}$ This paper is informed by reports of workshops and seminars conducted as part of the "Informal Transport Workers" project (2013-2016) of the International Transport Workers' Federation (ITF), by interviews with union representatives, by reports of activities undertaken by the union, and by additional participatory research fieldwork. We thank the Friedrich Ebert Stiftung in Uganda for their assistance and support. 
(WIEGO) (Bonner and Spooner, 2011; Bonner and Spooner, 2012).

However, there has been relatively little detailed research on the organisation of workers in the informal transport industry. A comparative study of informal transport workers' organisation in Benin, Zambia and the Philippines was undertaken by Christine Bonner and colleagues in 20052006, commissioned by the International Transport Workers' Federation (ITF). They concluded that many informal transport workers are already organised, but in associations rather than in trade unions (Bonner, 2006). Further research was undertaken in 2013-2016 by ITF-affiliated unions as part of the ITF's Informal Transport Workers Project, particularly in the Philippines, Cambodia, Colombia, Costa Rica, Nepal, Uganda, Kenya, Tanzania and Niger. This confirmed the presence of many associations of informal transport workers and explored the potential for building cooperation between these associations and the trade union movement. Most importantly, it demonstrated the potential for trade unions representing "formal" transport workers and associations representing informal workers to gain significant power as the result of cooperation (Spooner and Whelligan, 2017). Most dramatically, the Amalgamated and Transport General Workers' Union (ATGWU) took the initiative to build relationships with associations of informal transport workers in Uganda, leading to the union's transformation into a mass organisation of informal workers.

This article is based on evaluations and reports of workshops and seminars conducted as part of the Informal Transport Workers Project, interviews with union and association leaders, focus group discussions with the ATGWU Informal Sector Committee, Informal Sector Women's Committee and Staff and Management Committee, held in Kampala and Entebbe in February-March and JulyAugust 2016. Interviews were also held with the relevant ITF staff in London in September 2016. ${ }^{2}$

\section{Crisis and Renewal in Uganda's Transport Union}

The ATGWU was the first labour organisation in Uganda. In common with most sub-Saharan African transport unions, its membership and power has suffered almost continual decline in recent decades, particularly through the collapse of state-owned passenger road transport services and the informalisation of the entire sector. Crises caused by structural adjustment programmes (SAPs) in the 1980s and the consequent mass retrenchments pushed workers and unions to the wall. The older public transport companies operating large buses collapsed. Informal minibuses (referred to as taxis) and motorcycle taxis (boda-bodas) became the backbone of public transport.

The old bus companies had been the core of the ATGWU's organisation, and membership slumped. By 2006, according to Usher Owere, the National Chairman of the ATGWU and Chairman of the National Organisation of Trade Unions (NOTU), the union had a combined membership as low as 2 000, mostly concentrated in the airports. Most workers, and even their leaders, did not understand workers' rights or the role of trade unions, let alone that informal workers had the same rights as workers in the formal economy.

"After structural adjustment programmes and privatisation, Uganda was now a new form of raw capitalism, in which you were either rubbed out or built your own power", explains Owere (Interview, 29 July 2016). NOTU was also very weak. Some unions had literally no members; others

$2 \mathrm{~A}$ list of these interviews appears at the end of this article. 
had dwindled to virtually nothing. According to Baligasima Yazidi, NOTU Programmes Officer, there were attempts to discuss organising, but some union leaders did not understand, or simply did not want to understand, the need to organise outside the formal economy. According to Yazidi, there is still resistance to organising informal workers in the broader Ugandan trade union movement, particularly among public sector workers and in unions who see themselves as "professional bodies", such as nurses and teachers.

A change of ATGWU leadership in 2006 ushered in a new way of thinking for the union. The new leadership identified several priorities. These included making the ATGWU visible to all working people, ensuring that the union was relevant to workers, training the union leadership at all levels, and organising to rebuild the membership. To achieve this, the union needed to ensure that there was "service delivery" to its members - real benefits through collective bargaining, promoting the union as belonging to the workers themselves, and protecting its members. The ATGWU's change in perception and approach was supported by the union's sponsorship of university education for the leadership, which encouraged an understanding of the informal economy. The leaders also attended international seminars, exchange visits and other discussions organised by the International Labour Organization (ILO), NOTU, StreetNet International and the ITF.

In 2012, Aziz Kiirya was elected as the new General Secretary; he was committed to regenerating the ATGWU through the organisation and representation of informal workers. Although the former General Secretary had been instrumental in changing the ATGWU constitution to accommodate informal workers, he was reluctant to deploy union resources to organise in the informal sector. This would explain the slow pace of affiliation in 2006-2012, when only one association was registered: the airport taxi drivers. However, the election of Kiirya heralded a new direction. He secured the support of the National Chairman to deploy union resources, both human and financial, towards organising informal economy associations.

\section{Power Resources $^{3}$}

\section{The informal transport associations}

It is evident that informal transport workers, especially in urban passenger transport, have considerable structural power (Silver, 2003: 13ff.), based on their ability to cause major disruption in towns and cities. This is largely through workplace bargaining power, where the workplaces are the taxi ranks, the boda-boda stages and the streets where they operate. They can and do take industrial action and withdraw their labour. However, this action is not normally directed against employers, but rather against government and other public bodies that influence or control their day-to-day livelihoods and working conditions. They obviously also have circulation or logistical power (Webster, 2015: 11), the ability to cause major disruption to a city simply by simply bringing traffic to a standstill (not difficult in Kampala!) through mass mobilisation of taxis and boda-bodas.

The second form of structural power, market bargaining power, is only available to a relatively small

\footnotetext{
${ }^{3}$ Stefan Schmalz, Carmen Ludwig and Edward Webster describe the theoretical underpinnings of the power resources approach in detail in the Introduction to this Special Issue. The discussion here proceeds from that base.
} 
number of workers, mostly men, in the informal transport economy. The Ugandan economy is far from a tight labour market; few workers possess "rare qualifications and skills demanded by employers" (Silver, 2003: 13), and the oversupply of unskilled workers, a phenomenon that can be observed across the economy, significantly undermines the bargaining power of transport workers.

Nevertheless, there are discernible hierarchies between the informal workers and their formal economy (and unionised) counterparts which, as Schmalz and Dörre (2016) suggest, "harbour the risk of stripping workers of their sense of solidarity for each other. Such divides become clear in particular in the informal sector in the Global South". This was one of the central questions addressed in a specially convened ATGWU Strategic Development Retreat meeting, held on 21-23 November 2016. It brought together the leaders of informal workers' associations and ATGWU representatives of formal economy workplaces to build common understanding and discuss possible constitutional reform for the ATGWU to give equal rights and status to formal and informal economy union members (Spooner and Mwanika, 2016). It was undoubtedly true that prior to the meeting, there were some tensions between formal and informal workers' representatives, particularly among the formal workforce where they had no experience of directly engaging with informal association leaders. Yet these tensions appeared to be decreasing as the formal and informal leaders were able to grasp the potential power and mutual advantages of solidarity within a large integrated union. Whether this will be reflected among the rank-and-file members remains to be seen.

Such hierarchies are also to be found within the informal economy. Analysis of employment relationships between different occupations reveals distinct hierarchies within the informal transport industry. Those with skills (e.g. drivers) or owners of vehicles have a degree of market bargaining power, potentially exercised to maintain their position against others (e.g. conductors) who may aspire to become drivers or owners. Dispatchers may aspire to become conductors, and so on. Those with more market bargaining power are almost certainly men, with women facing segregation or discrimination, and far more likely to be found in the most low-paid, low-status and precarious occupations.

Some Ugandan informal transport workers have developed considerable associational power. Workers in the taxi/minibus terminals (the Kampala Operational Taxi Stages Association, KOTSA) and boda-boda riders (Kampala Metropolitan Boda-Boda Association, KAMBA), for example, have a combined membership of perhaps 70000 workers, probably more than the combined membership of NOTU. In those terminals where KOTSA has control, their workplace bargaining power is undeniable. In comparison with the trade unions, these associations have significant infrastructural resources, both money and human resources. Contrary to stereotypes, many of the workers especially in KAMBA - are highly educated, including graduates, with strong organisational and entrepreneurial skills, capable of sustaining organisational efficiency. There appears to be strong and active membership participation and internal cohesion. Until affiliation with the ATGWU, however, the informal associations had very weak or non-existent institutional power. They were not formally recognised by local or national governments, nor were they included in tripartite structures or processes.

There is also little indication of societal power. In general, taxi workers and boda-boda riders are unpopular in much of the media and public opinion. They are sometimes regarded as violent, dangerous, rude and responsible for the poor state of urban transport. KAMBA and KOTSA have a mixed reputation, with some regarding the formation of the two organisations as good initiatives, but 
there is no serious cooperation with broader social movements such as NGOs. Their discursive power or ability to effectively intervene in public debate is thus limited.

The capabilities of informal transport workers to recognise and use power resources strategically is limited (Lévesque and Murray, 2010). The capabilities around intermediating, framing and articulating are not well-developed, partly due to the relatively short histories of the main associations (notably KAMBA and KOTSA), although they have demonstrable learning capability and organisational flexibility.

\section{The ATGWU}

Prior to the affiliation of informal associations, the ATGWU had considerable structural power, but it was limited to a few workplaces. By far the most important source of workplace bargaining, circulation and multiplicative power is Entebbe Airport and the Civil Aviation Authority, which is well-organised with high union density - including the Airport Taxi Association, Entebbe Air Cargo Carriers Association and Entebbe Casual Labourers Association. This is the ATGWU's core formaleconomy power base and, as noted above, it remains crucial leverage in negotiations with government in securing trade union rights for informal workers.

Outside of the aviation and security industries, the ATGWU had virtually no associational power. It retains some infrastructural resources, with a relatively stable but limited income from its formal economy, dues-paying membership, and a small team of experienced and educated organisers and support staff. Organisational efficiency, membership participation and internal cohesion are weak, with democratic and constitutional structures and procedures in need of urgent reform. However, the ATGWU does continue to hold considerable institutional power. It has formal recognition and bargaining arrangements with the government and employers. The ATGWU leadership is able to intervene with the Ugandan political system, up to and including the State House. This proved crucial in overcoming police harassment in the process of the associations' affiliation.

The union has some limited societal power. It enjoys a certain amount of public respect and access to a reasonably sympathetic media, although overall public perception of the trade union movement as an important societal force is negligible. The ATGWU developed some important alliances and forms of cooperation through its HIV/AIDS programmes, and respect for its work in various related technical working groups. It also has a growing reputation for its work around the environment and climate change, especially in the broader Ugandan labour movement.

The ATGWU has strong capabilities in intermediating, framing and articulating. The leadership and staff have skills and experience in developing a collective interest from conflicting demands, framing the discourse and formulating new strategies, and articulating analysis and strategy locally, nationally and internationally. It has certainly demonstrated the ability to learn, both from understanding its own history and from interaction with national, regional and international trade unions, academic institutions and support organisations.

The ATGWU's intermediating capabilities were clearly demonstrated in the Strategic Development Retreat meeting in November 2016, which had a major impact on the development of a new sense of informal-formal solidarity and common purpose - that a large, fully integrated union

could have substantial societal, economic and political power in Uganda. These capabilities will be 
much-needed in the coming months to consolidate this through the period of expansion and transition towards constitutional and structural reform.

\section{Building Power}

\section{ATGWU engagement with informal economy associations}

The ATGWU strategy for organising informal economy workers was based on an understanding that these workers are in many cases already organised, not within the trade union movement but through credit and savings cooperatives, informal self-help groups, community-based organisations, and, most importantly, associations. Some of these associations were already large, well-organised and had substantial resources.

Rather than attempting to recruit individual informal workers into union membership, the ATGWU undertook a sequence of discussions and education events with some of these associations, eventually affiliating each association to the union. The process involved a sequence of engagements with associations, each leading to contact with the next. In each case, after initial discussions, the ATGWU "mapped" the association - developing an understanding of the membership, the issues they faced, their internal structure and so on. The union and association would then negotiate a memorandum of understanding and affiliation.

The first association to affiliate was the Airport Taxi Operators Association in 2008. The taxi drivers faced major problems, including lack of recognised parking space, chaotic passenger relations, lack of identification cards and police harassment. Inspired by discussions in an ITF seminar on organising precarious workers held in Lusaka in 2008, ATGWU leaders surveyed the drivers' working conditions, initiated discussions and training, and affiliated the association into the union. The Long Distance Heavy Truck Drivers Association and the Uganda National Lorry and 'Transporters' Association affiliated in 2014, but there had been a history of cooperation with the ATGWU dating back to 1999. This had been the ATGWU's first experience of engaging with informal workers - a by-product of the ITF's longstanding work on HIV/AIDS in East Africa. The Entebbe Cargo Carriers Association and the Entebbe Casual Labourers Association, influenced by the benefits the airport taxi drivers were gaining through union membership, affiliated in March 2014. This was followed by the Galima Fights HIV/AIDS Initiative, an informal community-based association supporting HIV/AIDS survivors, and the Uganda Bus Drivers and Allied Association, both referred to the union by NOTU. In June 2014, the Nagojje Motor Cycle and Bicycle Transporters Association affiliated on the recommendation of the Uganda National Lorry and Transporters Association. The following month, the Entebbe Stages and Conductors Association (ESCADA) affiliated, representing minibus operators and conductors. In January 2015 a group of mostly women home-based craft workers - the Tukolere Wamu Crafts and Development Association - affiliated. Closely related to Galima, the association runs weekly wholesale markets near a major transport intersection in Kampala, selling crafts for the tourist trade.

All of these affiliated associations were relatively small - representing a total combined new 
membership of 4473 workers. ${ }^{4}$ This changed dramatically with the affiliation of two large and powerful associations - the Kampala Operational Taxi Stages Association and the Kampala Metropolitan Boda-Boda Association in 2015.

KOTSA was the first major association to join, representing 36000 taxi (minibus) drivers and conductors organised in the Kampala taxi ranks, or stages. The membership of ESCADA, which organises workers at each end of the Entebbe-Kampala road, overlaps with KOTSA, and ESCADA played a major role in introducing the idea of ATGWU membership to KOTSA. KOTSA had been facing numerous problems, particularly regarding the law forbidding gatherings of more than ten people without permission unless they were a union. The 2013 Public Order Management Act gave the Inspector General of Police the power "to regulate the conduct of all public meetings in accordance with the law", but trade unions were explicitly exempt.

The process of affiliating KOTSA led to running battles between the ATGWU and the police. At one time the police in effect occupied the ATGWU compound and expelled the workers. This police action was firmly resisted by ATGWU leaders, who declared that organising the taxi drivers was a bona fide trade union activity, as permitted by law. The ATGWU immediately announced to the media that it was calling a strike in protest against the police closure of its offices, threatened to shut down the airport, and - with KOTSA membership on the streets - to bring Kampala to a standstill. The Inspector General of Police responded by calling a meeting with ATGWU leaders. At the same time, the ITF had written to President Museveni in protest at the police action. Prompted by Museveni and fearing an escalation of action by the ATGWU and KOTSA, the Inspector General backed down. He publicly apologised, the union agreed to call off the strike and KOTSA affiliated to the union.

The confrontation and subsequent victory proved to be a pivotal moment for the ATWGU in the organisation of informal workers. The whole event was widely publicised in the media and had an enormous impact on the morale and confidence among informal association members. It was not only a victory against police interference in the business of the associations, but against the day-today police harassment and extortion suffered by informal transport workers. It was also widely believed to be a victory against political interference. Union and association leaders are convinced that the police action was not motivated by a misunderstanding of the law, but that they were acting on behalf of the rival association affiliated to the Central Organisation of Free Trade Unions (COFTU).

KAMBA, representing 38000 boda-boda riders, had been suffering similar police harassment and interference. They joined the ATGWU in September 2015. The ATWGU's victory in enabling KOTSA to gather and hold elections without police harassment strengthened KAMBA's interest in joining.

Launched in January 2014, KAMBA had become a significant organisation with a wide range of services for their members. KAMBA first began discussions with the ATGWU in 2014 at a meeting

${ }^{4}$ Throughout this paper, unless otherwise stated membership figures of associations are those included in the memorandum of understanding between each association and the ATGWU signed at the point of affiliation. This is to avoid confusion between various estimates of membership, depending on the criteria used (numbers of paying members, registered members, numbers of workers in workplaces managed by the association, etc.). 
to discuss a threatened strike by boda-boda riders. ${ }^{5}$ The ATGWU General Secretary attended and presented the benefits of joining the union to defend KAMBA members' rights. He explained that the proposed strike was illegal unless called by a registered trade union. This was followed by a press conference at the ATGWU offices at which the strike was called off. The press conference and subsequent media coverage did much to galvanise support and boost membership for KAMBA, which further strengthened the case for affiliation.

\section{Benefits of affiliating with the ATGWU}

In February 2015, the union established the Informal Sector ${ }^{6}$ Committee, composed of the Chairpersons and Secretaries of all the affiliated associations. The Committee holds monthly meetings hosted by all the affiliates in rotation. This has worked very well, enabling all the member organisations to get to know one another, engaging members and not just the leadership. The informal associations represented on the Informal Sector Committee unanimously believe that they have seen a " $100 \%$ increase in power for everyone" as a result of affiliating to the ATGWU. Most importantly, there has been a reduction in police harassment, particularly after the confrontation over the KOTSA elections. The Entebbe Cargo Handlers Association explains that they no longer fear the police, and harassment stopped simply as the result of wearing ATGWU T-shirts. KAMBA has noted a sharp decline in the harassment of boda-boda riders since the statement by the Inspector General of Police.

There have also been substantial gains through collective bargaining with ATGWU support. The airport taxi drivers engaged in collective bargaining with the Civil Aviation Authority, which manages the airport. This led to standardised branding for the taxis, an office and sales counter for the association in the arrivals hall, a properly organised parking and rest area, uniforms and identity cards, and a substantial reduction in the number of instances of police harassment and extortion. The Tukolere Wamu market traders were devastated when their market was demolished by the authorities. The ATGWU intervened and engaged in negotiations with the Kampala Capital City Authority (KCCA). The demolition order was rescinded and the market re-established.

ATGWU's training has been very effective in boosting confidence, especially in the management of associations with regard to the role and rotation of leadership and conducting meetings. According to the Informal Sector Committee, there is a noticeable difference between people who have attended training and who have not. Committee members believe that trusted and experienced ATGWU staff and leaders have been able to provide valuable advice and support to strengthen internal democratic procedures and rules, which has reduced internal conflict in the associations and greatly helped to eliminate vote-rigging and other election irregularities.

Union membership cards and particularly ITF international identity cards have proved to be very valuable. The members of both the Long Distance Heavy Truck Drivers Association and the

\footnotetext{
${ }^{5}$ Focus group discussion with ATGWU Informal Sector Committee, 30 July 2016.

6 Since the ILO discussions of 2002 , the term "informal sector" has been generally replaced by "informal economy", reflecting the fact that informality is not a sector in itself, but that the informal economy is to be found in virtually all employment sectors.
}

${ }^{7}$ Focus group discussion with ATGWU Informal Sector Committee, 30 July 2016. 
Airport Taxi Operators Association have benefited greatly from the help of ITF-affiliated unions when needing assistance while abroad. Taxis are frequently hired from Entebbe airport to travel across borders into neighbouring countries.

According to David Musoke, Chairperson of the Informal Sector Committee, the main overall benefit of being affiliated to the ATGWU is the support of union leaders with strong connections and reputations. To be part of the ATGWU was to be part of an "honourable name". In 2014, his association had a serious problem with the Executive Director of the KCCA who was behaving "very arrogantly" towards the drivers and refused to negotiate. The ATGWU opened the door to negotiations, providing "respect and access". The Entebbe Cargo Handlers Association recognises that the ATGWU has given them "a bigger voice with the government and authorities". KOTSA explained that President Museveni has tried to persuade them to leave the ATGWU, that it was causing the government "inconvenience". Previously the President had refused to recognise them.

\section{The impact of union affiliation on women workers}

At an early stage of the ITF project, the ATGWU encouraged the establishment of women's committees in each of the newly affiliated associations. The union founded an ATGWU Informal Sector Women's Committee to support mapping and organising, and to organise activities to promote the visibility of women in informal transport. These committees have become important channels for encouraging the participation of women.

The number of women working in "core" transport industry jobs remains small, but it is growing. KOTSA counts only forty-five women conductors, thirteen drivers, sixty "call-girls" ${ }^{8}$ and twenty ancillary workers out of a total membership of approximately 36000 . The Entebbe Airport Taxi Association, with a membership of 250, has only two women members - one a secretary and one a driver. KAMBA has only twenty to thirty women riders out of a membership of 38000 . There are, however, many more women working in and around the major transport hubs, among whom the ATGWU is organising. Some of the major issues faced by the women workers are the same as those facing other informal workers more generally throughout the world - low pay, long hours, dangerous and unhealthy working conditions, and lack of social protection. However, the most important issues identified by the women in all the countries where mapping was undertaken was violence, sexual harassment and intimidation by men. Vehicle owners, and some leaders of the associations themselves, are major barriers to addressing and ending the violence and discrimination, but committee members believe that the biggest barrier is the lack of education among the women, particularly the lack of awareness of their rights and fear of the police. This is the most important task for the Informal Sector Women's Committee.

The ATGWU arranged education workshops for the women, as well as more informal education work on the streets, in the major transport hubs and within the union itself. According to the women, this is effective in changing attitudes among the men, and it has given women more confidence in describing their experiences. The men have become more supportive.

On 29 March 2016, the committee organised a convoy of twelve minibus taxis on a round trip along one of the major taxi routes from Kampala to Entebbe, a distance of $45 \mathrm{~km}$. The objective was

8 "Call-girls" and "call-boys" are people informally employed in minibus taxi and bus terminals as despatchers. They are paid by drivers to fill vehicles with passengers as quickly as possible. 
to demonstrate that women can and do work in the taxi industry, to encourage other women to do so, to show that they can run taxis on equal terms with men, and to demand equal rights. The event reached the news headlines and created considerable media attention, with well-known media personalities and TV crews accompanying the women's taxis on the Entebbe trip. Women watching the news were immediately inspired to phone the union, wanting to join.

Nevertheless, the informal transport industry in Uganda is huge. There are estimated to be more than 250000 boda-boda drivers in Kampala alone. There are more than 50000 taxis, providing work for an entire micro-economy of drivers, conductors, call-boys, call-girls, mechanics, tyre-fitters, cleaners, ticketing clerks, painters, sound system engineers, guards and others. In this context, the ATGWU's Informal Women's Committee has only just scratched the surface. Yet the ATGWU Informal Sector Committee (comprising both men and women) points out that KAMBA's General Secretary is now a woman, that every one of KAMBA's five offices is run by a woman, that there are increasing numbers of women working as conductors, and that the women leaders who have emerged over the last three years are now very important role-models for women.

\section{Implications and Challenges}

The extraordinarily rapid expansion in membership and the revitalisation of the ATGWU into a union that is developing significant power in the Ugandan transport industry is remarkable. Yet it presents serious new challenges for the ATGWU.

\section{Equal status for formal and informal workers}

There is general agreement between the leaders of both the ATGWU itself and of the newly affiliated associations that the current constitutional, governance and management arrangements need to be reformed. The informal workers should have the same rights and responsibilities as their formal economy counterparts to ensure full participation in the trade union movement. To that end, the ATGWU has agreed in principle that there should be a transition towards full individual ATGWU membership of affiliated association members, with equal democratic rights and responsibilities to those of formal economy workers (Kiirya, interview, 29 February 2016). This includes the payment of individual dues by the informal workers after thorough discussions on the amount and mode of payment.

If practical arrangements for payment could be agreed, presumably through the associations, and all the approximately 57523 members of all affiliated associations paid, this would theoretically generate new income of UGX 690 million, the equivalent of more than US\$200 000. This compares with the estimated total of association affiliation fees payable in 2015 of UGX 7650000 (US\$2 250). ${ }^{9}$ Even if it proved impossible to efficiently collect payments from all members, it would still mean a huge increase in income for the ATGWU.

On the other hand, as the ATGWU Chairperson acknowledges, the increase in affiliations and mass membership creates an enormous demand for "service delivery" which would require major

9 As reported to the Informal Sector Committee Retreat meeting, December 2015. These are the figures agreed by the associations, but not necessarily paid. 
changes in the number of staff members and elected officials and their responsibilities (Owere, interview, 29 July 2016). At present, the informal workers' associations have one representative on the National Executive Board, an arrangement agreed after the first association affiliated, but this is not reflected in the constitution and the affiliated associations have not undertaken a formal election process to determine their representatives since the original decision.

Full members of the ATGWU are constitutionally obliged to pay 2 per cent of their salary in union dues. This would of course be extremely complicated for informal workers, most of whose income varies considerably from day to day or year to year, and many are highly transient, both in terms of workplace and residential address. Additionally, few have bank accounts, although the rapid expansion of mobile phone transfers (Mobile Money) in Uganda may offer new solutions to dues collection.

\section{Formal-informal solidarity}

Since the formation of the ATGWU Informal Sector Committee there has been remarkably strong solidarity between the associations, but it was recognised that there was a need to bring informal and formal members of ATGWU together to develop solidarity across the formal-informal divide. ${ }^{10}$ The ATGWU team of staff and elected section secretaries recognised that very few of the union's shop stewards in formal workplaces are aware of or understand the strategy to organise in the informal transport industry (Focus group discussion, 1 August 2016). Some of the "formal" union leaders were thought to be resistant, as they feared that large numbers of new members from the informal economy would pose a major threat to their elected positions. Some, including some National Executive Board members, believed that there was far too much emphasis on the informal economy, and that the formal workplaces were being neglected despite making a major contribution to the union's income. There had been very few training opportunities for formal workplace representatives and therefore a very low understanding of trade unionism.

The union has a long-standing National Women's Committee, elected every five years at the union's Congress. The women elected to this committee are all from the formal transport industry primarily in aviation. There had been little contact between the formal and informal women's committees, but according to the informal women, there was potential for solidarity and mutual support and a need to build mutual understanding. The problem was exacerbated by lack of regular meetings of the ATGWU's key constitutional bodies, where representatives of the formal economy workers would normally discuss policy and strategy. This meant that there had been little or no opportunity to develop a dialogue, encourage mutual respect or develop solidarity between the formal and informal committees. ATGWU staff recognised the problem as well as the need to bring the two committees together to develop a joint education programme. It was also recognised that many of the young leaders and activists in the informal associations are highly educated and are likely to demand far greater accountability and transparency in the union's management.

According to the members of the Informal Sector Committee, the creation of a very big union will attract a great deal of interest - and potentially interference - from the political parties, especially from the ruling National Resistance Movement (NRM) and the opposition Forum for Democratic Change (FDC), which could provoke major internal divisions within the ATGWU. Current ATGWU

${ }^{10}$ Informal Sector Committee focus group discussion, 30 July 2016. 
leaders support a variety of parties including the NRM, the FDC and a variety of smaller groupings, and there is an implied agreement that no one should use the union as a party-political platform. An issue emerges in the fact that informal transport workers and their associations play a very prominent campaigning role in Ugandan elections, particularly the boda-boda riders (albeit very frequently for financial incentives).

According to Baligasima Yazidi from NOTU, the government is very unhappy at the affiliation of KOTSA and KAMBA to the ATGWU, and thus their exemption from the provisions of the 2013 Public Order Act that limits the right to assembly (Yazidi, interview, 1 August 2016). From NOTU's perspective the government always attempts to divide and rule the trade union movement, citing the experience after 2003 when they supported the establishment of the rival Central Organisation of Free Trade Unions, and fifteen "duplicate" unions. He believes that there is a strong possibility that the government may now try to split the ATGWU, inciting and exploiting internal divisions (Yazidi, interview, 1 August 2016).

\section{Transition to a fully integrated union}

In November 2016, partly due to discussions held as part of the research leading to this paper, the ATGWU Chairperson and General Secretary proposed that leaders from the ATGWU and its affiliated associations meet in a "retreat" meeting to discuss the future development of the ATGWU and to build mutual trust and understanding across the group. More specifically, the retreat was meant to consider ideas for a transition process from current affiliation arrangements to integration of informal workers into the ATGWU as full members with equal rights and obligations to those in the formal economy. These discussions were held in preparation for the then forthcoming ATGWU 2017 Quinquennial Delegates Conference, where delegates would consider proposals for constitutional reform and a strategic plan for 2017-2022. The three-day retreat was attended by thirty-nine union and association leaders, including members of the ATGWU's National Executive Board and Informal Sector Committee.

The retreat had no formal decision-making power but provided a democratic space for open discussion. ${ }^{11}$ The recommendations and conclusions emerging from the retreat were those of the retreat participants themselves, designed to be presented to the governing bodies and relevant committees of the ATGWU and the affiliated associations for consideration and decision. At the conclusion of the retreat, participants made several recommendations. These included measures to achieve full integration of informal workers, strengthened democratic governance (particularly for financial accountability), a review of and options for amending the ATGWU constitution, improved communications, expanded engagement of women, priorities for union education, and the 20172022 Strategic Plan (Spooner, 2016). Most importantly, the retreat meeting was remarkably successful in building solidarity and trust between the participants, and there was a clear sense that it was a historic moment in the creation of a new and powerful integrated union.

\section{The role of the ITF}

The broad idea of building alliances and working with informal economy associations had been

${ }^{11}$ The meeting was facilitated by Dave Spooner of the Global Labour Institute at the request of the ATGWU. 
circulating in the ITF for some time. Indeed, the 2010 Congress document noted that "while some of these workers have organised into trade unions, there is a need to recognise and to work with other forms of worker organisation which precarious workers have developed among themselves, and to link them to the trade union movement" (ITF, 2010: n.p.).

Nevertheless, it cannot be said that the transformation of the ATGWU was due to ITF strategy. Arguably, it is more likely that the ATGWU's experience, along with that of the other "mentor unions" in the project, is having an important impact on the ITF's own strategic thinking. The original shift in strategy by the ATGWU in 2012 was the result of a combination of influences university courses attended by senior officials; participation in debates and discussions on the informal economy at the ILO, ITUC and other international trade union meetings and seminars; the development policies of major donor agencies; contacts with WIEGO, StreetNet International, the Global Labour Institute (GLI) and other NGOs working on the informal economy; and informal discussions with others in the ITF Africa Region, for whom the challenge of informal work was a high priority.

The informal workers project was an initiative of the ITF's Education Department, with the majority of costs covered by a grant from FNV Mondiaal (the Netherlands Trade Union Confederation). Although under the management of an ITF steering committee, with representation from the Inland Transport Department, the Women's Department and the General Secretary's Office, it was not in the mainstream of priority strategic campaigns. Aside from the ITF's Africa Regional Office, the project as a whole and the achievements of the ATGWU in particular were to some extent "under the radar".

This changed in December 2016, when ATGWU representatives, along with other mentor unions and the GLI, presented the outcomes of the project to a global conference of the Road and Rail Sections of the ITF held in Brussels. This was the first opportunity many of the senior elected representatives and officers of the ITF had to hear directly from the unions concerned and to appreciate the success of the organising model. For some of the unions from the Global North, who face the growth of precarious employment and the "gig economy" in transport, there was recognition that these strategies were of considerable potential importance across the whole of the ITF.

The experience of the ATGWU is also important in addressing the ITF's concerns about the future sustainability of unions in developing countries, particularly in Sub-Saharan Africa and South Asia. By rebuilding a mass organisation of transport workers through the affiliation of informal workers' associations, the ATGWU is poised to become fully self-sustainable financially. The associations have systems in place for the collection of membership dues which are clearly sustainable, requiring no external support for them to function. ${ }^{12}$ If this model could be replicated elsewhere, it would have very positive consequences for the ITF itself.

Mac Urata, ITF Section Secretary for Inland Transport over the duration of the project, thinks that mass membership may have a huge impact in the near future:

12 As the result of the ATGWU experience, the ITF is currently assessing the feasibility of developing mobile banking applications for use in countries such as Uganda and Kenya, which would simplify the task considerably. 
It may be too early to say, but ATGWU is the best model we have in presenting the case for mass membership of informal transport workers. Clearly there is a need for ATGWU to review its structures, activities and services, but if income is generated, there is a good chance of creating a real and sustainable trade union of informal workers. The union has a long and respected history, both regionally and internationally. It cannot get better than this (Urata, interview, 1 September 2016).

\section{Conclusion}

Is the Uganda organising model replicable? Those in the ITF who have been directly involved in the project or have been able to gain first-hand experience of working with the ATGWU and the informal workers' associations believe that it is, at least potentially. This was the view echoed by the delegates at the ITF Road and Rail conference.

In common with other global union federations, the ITF faces a continual dilemma of how to be democratically inclusive of all affiliated unions, regardless of size or resources, yet avoid the enormous expense of servicing the many small and weak unions who cannot afford more than a token financial contribution. The multi-layered democratic structure of the ITF - with regional, sectoral, youth and women's structures - includes numerous international committees and conferences, as well as the quadrennial Congress itself. The cost of ITF subsidy for the participation of unions with few resources far outweighs the income they generate, and the outcomes of these meetings, such as practical organising initiatives and coordination of activity, are frequently of questionable value. If the affiliation and integration of mass-membership informal associations into ITF unions can be extended and maintained, it would be a major step forward towards the sustainability of the ITF as a whole in developing countries.

Yet there is a remaining question of how far the affiliation of the large associations has been influenced by the peculiarities of Ugandan law. The ATGWU was able to offer the associations protection from police interference and harassment under the 2013 Public Order Management Act. Nevertheless, the "ATGWU model" has already been successfully adopted and adapted by other unions involved in the ITF project, particularly elsewhere in East and West Africa.

And what has been the role of power resources in the transformation of the union? The process of transformation of the ATGWU through the affiliation of a mass membership of informal transport workers can be summarised as a union with declining associational power, but with residual structural and institutional power, combining with informal workers' associations possessing considerable associational and structural power, but with no access to institutional power. Both benefit, and the result is a union transformed into a large and potentially very powerful organisation uniting informal and formal economy workers. Both previously had limited societal power, but with the combined capabilities, this perhaps now becomes possible if the necessary transition process is successful.

\section{REFERENCES}

Bonner, C. (2006) Organising Informal Transport Workers: Global Research Project Overview Report. http://www.itfglobal.org/media/1382/08e report.pdf (accessed 13 February 2017).

Bonner, C. and D. Spooner (2011) Organizing Labour in the Informal Economy: Institutional Forms and 
Relationships. Labour, Capital and Society, 44(1): 128-52.

Bonner, C. and D. Spooner (2012) The Only School We Have: Learning from Organizing Experiences across the Informal Economy. http://wiego.org/sites/wiego.org/files/resources/files/ Bonner Spooner The Only School We Have.pdf (accessed 13 February 2017).

International Labour Organization (ILO) (2002) Decent Work and the Informal Economy, Report VI. International Labour Conference, 2002. http://www.ilo.org/public/english/standards/relm/ilc/ilc90/pdf/rep-vi.pdf (last accessed 13.2.2017)

International Transport Workers' Federation (ITF) (2010) Strong Unions - Sustainable Transport. Congress Theme Document, ITF 42nd Congress, Mexico City, 5-12 August 2010. http:/ /www.itfcongress2010.org/files/extranet/-2/24484/Congress $\% 20$ Theme $\% 20$ Document $\%$ 2042nd\%20C-8\%20-1.pdf (accessed 13 February 2017).

Lévesque, C. and G. Murray (2010) Understanding Union Power: Resources and Capabilities for Renewing Union Capacity. Transfer: European Review of Labour and Research, 16: 333-50.

Schmalz, S. and K. Dörre (2016) The Power Resources Approach. Berlin: FES.

Silver, B.J. (2003) Forces of Labor: Workers' Movements and Globalization since 1870. Cambridge: Cambridge University Press.

Spooner, D. (2016) Negotiations and Strategy Training for Leaders/Organisers of Informal Transport Workers. http://www.informalworkersblog.org/download/947/ (accessed 13 February 2017).

Spooner, D. and J.M. Mwanika (2016) ATGWU Strategic Development Retreat - Summary Report, Global Labour Institute, Manchester.

Spooner, D. and J. Whelligan (2017) The Power of Informal Transport Workers. http://www.itfglobal.org/media/1691170/informal-transport-workers.pdf (accessed 1 May 2018).

Webster, E. (2015) Labour after Globalization. Old and New Sources of Power. In Labour and Transnational Action in Times of Crisis, edited by A. Bieler, R. Erne, D. Golden, I. Helle, K. Kjeldstandli, T. Matos and S. Stan. Lanham, MD: Rowman \& Littlefield.

\section{INTERVIEWS}

Unless otherwise stated, all interviews and focus group discussions were conducted between 25 July and 4 August 2016 in Kampala and Entebbe, Uganda.

\section{Interviewees and focus group participants}

Mr Usher Wilson Owere, National Chairperson of ATGWU and Chairman of NOTU

Mr Aziz Kiirya, General Secretary, ATGWU, 29 February 2016

Mr Joshua Ogilin, Labour Officer, Entebbe Municipal Council

Mr Vincent Tumusiime, Principal, East Africa Labour College

Mr Baligasima Yazidi, Programmes Officer, NOTU

Mr Stephen Kiide, Chairperson, Entebbe Stages Conductors and Drivers Association (ESCADA)

Mr Hamidu Ssebunya, Education Officer, Entebbe Stages Conductors and Drivers Association (ESCADA)

\section{ATGWU Informal Sector Committee}

Mr Bulago Bazirie, Committee Member, Entebbe Cargo Carriers Association 
Mr David Musoke, Committee Chairperson, Uganda National Lorry Drivers and Transporters Association Mr Lydia Nabakka, Assistant Secretary, Tukolere Wamu Crafts Development Association Mr Manteze Aisha, Woman Representative, Kampala Operational Taxi Stages Association (KOTSA) Mr Mutaawe Danda, Ex-Official, Uganda Long Distance and Heavy Trucks Drivers Association Ms Nakalenzi Fatuma, Committee Member, Kampala Operational Taxi Stages Association (KOTSA) Ms Ssemussu John, Committee Member Kampala Metropolitan Boda-Boda Association (KAMBA)

\section{ATGWU Informal Sector Women's Committee}

Ms Beatrice Nakayenga, Vice-Chairperson, Entebbe Stages Conductors and Drivers Association (ESCADA) Ms Consolata Zavuga, Committee Member, GALIMA Initiative on HIV/AIDS

Ms Elizabeth Makijoba, Committee Member, Uganda National Lorry Drivers and Transporters Association Ms Irene Nakiyemba, Secretary, Airport Taxi Operators Association Ms Lydia Nabakka, Ex-Official, Tukolere Wamu Crafts Development Association Ms Nuruh Mulindwa, Treasurer, Tukolere Wamu Crafts Development Association Ms Prossy Nampijja, Assistant Secretary, Kampala Metropolitan Boda-Boda Association (KAMBA) Ms Shanitah Birungi, Chairperson, Kampala Operational Taxi Stages Association (KOTSA)

\section{ATGWU Staff and Management Committee}

Mr Stephen Abima, Section Secretary (Programmes)

Mr Micheal Mubiru, Finance and Administration Officer

Ms Jane Atto, Section Secretary (Private Security)

Mr Ouma Mugeni, Section Secretary (Transport and Logistics)

Ms Nantongo Mastulah, Intern

\section{ITF Staff}

Interviews were conducted in London during September 2016.

Ms Alana Dave, Education Officer

Ms Jodi Evans, Women's Officer

Mr Stuart Howard, Assistant General Secretary

Mr Mac Urata, ITF Section Secretary for Inland Transport

\section{LIST OF ABBREVIATIONS}

ATGWU Amalgamated Transport and General Workers' Union

COFTU Central Organisation of Free Trade Unions

ESCADA Entebbe Stages and Conductors Association

FDC Forum for Democratic Change (Uganda opposition party)

FNV Federatie Nederlandse Vakbeweging (Netherlands Trade Union Confederation)

GLI Global Labour Institute

ILO International Labour Organization

ITF International Transport Workers' Federation

ITUC International Trade Union Confederation

KAMBA Kampala Metropolitan Boda-Boda Association

KCCA Kampala Capital City Authority 
KOTSA Kampala Operational Taxi Stages Association

NOTU National Organisation of Trade Unions

NRM National Resistance Movement (Uganda ruling party)

SAP Structural Adjustment Programme

WIEGO Women in Employment: Globalizing and Organizing

\section{BIOGRAPHICAL NOTES}

DAVE SPOONER is the co-director of the Global Labour Institute (GLI) in Manchester, an independent organisation providing research and education for the British and international trade union movement. The GLI specialises in trade union organisation in the informal economy and education programmes on international trade unionism, working with Global Union Federations and their affiliates. It coordinates the Informal Workers Project of the International Transport Workers' Federation.

JOHN MARK Mwanika is the Projects Coordinator and Secretary General: Duties at the Amalgamated Transport and General Workers' Union (ATGWU), and holds a Master's degree in Development Studies. He is responsible for designing the strategy that has led to the massive growth of the ATGWU's membership by affiliating informal transport workers associations. He sits on a number of policy working groups and is also chair of the Civil Society Coalition on Transport, Uganda (CISCOT) policy working group. 